Etnográfica

Revista do Centro em Rede de Investigação em

Antropologia

vol. 11 (2) | 2007

Vol. 11 (2)

\title{
Josep Maria Comelles, Stultifera Navis: La Locura, el Poder y la Ciudad
}

\section{Luís Silva Pereira}

\section{(2) OpenEdition \\ Journals}

\section{Edição electrónica}

URL: https://journals.openedition.org/etnografica/2064

DOI: 10.4000/etnografica.2064

ISSN: 2182-2891

\section{Editora}

Centro em Rede de Investigação em Antropologia

\section{Edição impressa}

Data de publição: 1 novembro 2007

Paginação: 494-496

ISBN: 0873-6561; E-ISBN 2182-2891

ISSN: 0873-6561

\section{Refêrencia eletrónica}

Luís Silva Pereira, «Josep Maria Comelles, Stultifera Navis: La Locura, el Poder y la Ciudad», Etnográfica [Online], vol. 11 (2) | 2007, posto online no dia 27 setembro 2012, consultado o 12 fevereiro 2022. URL: http://journals.openedition.org/etnografica/2064 ; DOl: https://doi.org/10.4000/etnografica.2064

Este documento foi criado de forma automática no dia 12 fevereiro 2022

\section{(c) (1) (9)}

Etnográfica is licensed under a Creative Commons Attribution-NonCommercial 4.0 International License. 


\title{
Josep Maria Comelles, Stultifera Navis: La Locura, el Poder y la Ciudad
}

\author{
Luís Silva Pereira
}

\section{REFERÊNCIA}

Josep Maria Comelles, Stultifera Navis: La Locura, el Poder y la Ciudad, Lleida, Editorial Milenio, 2006, 407 páginas.

1 Josep Maria Comelles, um autor de referência da antropologia médica, licenciou-se em medicina, na especialidade de psiquiatria, e foi médico residente no Instituto Mental de Santa Creu de Barcelona entre 1973 e 1976. Durante esse período descobriu a Antropologia social, encantou-se com o exotismo das narrativas dos antropólogos clássicos e meteu-se a caminho dessa disciplina, enquanto exercia psiquiatria, tendo concluído a licenciatura na Faculdade de Filosofia e Letras da Universidade de Barcelona e o doutoramento na École des Hautes Études en Sciences Sociales, em 1979 (a tese era sobre o manicómio barcelonês). De regresso à Catalunha, em Barcelona, em 1981, defendeu outra tese sobre políticas públicas de saúde mental em Espanha.

2 O trabalho de campo da investigação de que resulta a obra em referência decorreu entre 1973 e 1980, combinando observação participante, entrevistas a trabalhadores do Hospital e recurso ao arquivo histórico da instituição. A investigação foi retomada em 2001, intensificando o trabalho de arquivo e recorrendo, de forma mais moderada, aos outros dois instrumentos de pesquisa.

O resultado é este livro, onde a história de uma instituição - desde a sua fundação como hospital em 1401 e como manicómio em 28 de Dezembro de 1889 (o dia dos santos inocentes, como é designado pela tradição católica, ou dos loucos, segundo a designação popular) até ao seu encerramento (em 1986) - se cruza com as histórias de Barcelona, da Catalunha, de Espanha e do mundo europeu do século XX, que afectam e determinam a lógica organizativa dessa instituição. $O$ autor toma Barcelona como um bom exemplo da "glocalização" e faz a experimentação de uma "história total" (p. 381). 
Comelles segue o caminho aberto pela arqueologia foucaultiana (Histoire de la Folie à L'Âge Classique, 1961; Naissance de la Clinique. Une Archéologie du Regard Médical, 1963; Les Mots et les Choses. Une Archéologie des Sciences Humaines, 1966) e o seu texto remete para a encenação de uma ópera, estilizando acontecimentos e elementos cenográficos, na esteira de Taussig (Shamanism, Colonialism and the Wild Man, 1987) e Scheper-Hughes (Death Without Weeping. The Violence of Everiday Life in Brazil, 1992). No entanto, nem a situação política da Catalunha remetia para o Estado centralizado de que fala Foucault, nem a encenação de Taussig e de Scheper--Hughes implica o envolvimento afectivo e a descrição intimista e cúmplice que usa Comelles quando examina as várias fases pelas quais passou o manicómio, convoca a memória do seu tempo de trabalho na instituição e avalia o seu envolvimento com a profissão e as expectativas que desenvolveu em relação a ela.

Desde o início da obra que o leitor é instado a compreender a singularidade do confronto de culturas políticas distintas, a da Catalunha e a do Estado espanhol, em múltiplas lutas que se desenrolaram em diferentes momentos históricos. As relações de hegemonia e subalternidade entre classes e estratos tornam-se mais complexas pela determinação do mercantilismo e do capitalismo, os quais vão complicar ainda mais a construção de uma sociabilidade colectiva, segundo o autor (p. 50), que considera igualmente indispensável, para entender a loucura e a sua relação com a cidade, perceber como se vai tecendo a teia que liga a Igreja, a classe dirigente, a instituição e a cidadania (p. 57).

5 Na obra, Comelles revela as regras de funcionamento do sistema de saúde e o modo como orientam a prática assistencial, desfia a história de Barcelona e dos choques entre os desideratos políticos da Catalunha e a lógica centralista e autoritária do conservadorismo nacionalista, e faz o enquadramento destes conflitos no concerto europeu de forças e violências abrangentes que fazem da vida dos indivíduos envolvidos na instituição em estudo um grão de areia ínfimo numa imensa praia de interesses económicos e políticos, nacionais e internacionais.

$\mathrm{O}$ autor demonstra (através da análise de um conjunto impressionante de documentos que coligiu) como não faz parte dos objectivos dos dirigentes da instituição e do pessoal que assistia os doentes (constituído, inicialmente, por elementos integrantes de ordens religiosas e, posteriormente, por agentes de saúde legitimados pela biomedicina) a intenção de curar os internados na instituição. Segundo Comelles, a conduta dos doentes fundamentava o encerramento e a psicopatologia justificava-o e racionalizavao, "atribuindo autoridade ao psiquiatra e ao psicólogo e permitindo a justificação médica de formas de violência e de arbitrariedade terapêutica" (p. 278; esta e as seguintes traduções são minhas). A lógica capitalista formata a profissionalização da função assistencial e a organização institucional: a rentabilidade torna-se fundamental no modo como os directores encaram a instituição e os seus valores patrimoniais, imóveis e outros. A especulação imobiliária e a rentabilização dos terrenos institucionais tomam a dianteira nas preocupações dos dirigentes da instituição e, como diz Comelles, torna-se claro que "o louco serve para justificar decisões políticas e resolver conflitos de interesses” (p. 366).

7 A individualidade dos internados é, por sua vez, limitada pelo estatuto de doente, o indivíduo internado reduz-se aos olhos dos que o cuidam, à doença que o acomete e, se o seu estado de saúde o permite, às funções que lhe estão atribuídas na instituição. Trabalhadores e internados estão presos por uma lógica organizacional que os confina 
dentro dos limites das paredes da instituição, intransponíveis desde dentro para fora, mas extremamente permeáveis às mudanças que se vão verificando na sociedade alargada. A filosofia, a organização e os quadros directivos da instituição vão mudando de acordo com os interesses económicos de uma cidade que vai crescendo e com a valorização imobiliária dos terrenos do hospital.

8 A "história total" tecida por Comelles é ilustrada por 135 fotografias. Esses documentos transportam-nos a outras épocas e a lugares inesperados, introduzem-nos em salas e corredores, pátios e arcadas, campos e caminhos, apresentam-nos gravuras, mapas e esboços, confrontam-nos com olhares perturbadores, situam-nos em cenários da guerra civil espanhola, levam-nos, pela mão do olhar do autor, a cheirar e a sentir os húmidos ambientes onde a luz e a penumbra jogam às escondidas com o nosso olhar, ocultando $\mathrm{e}$ revelando seres, intenções, recantos, destapando a carne e a alma do humano tornado próximo pela câmara. Lançados para cenários desoladores, somos obrigados a ser mais do que meros e protegidos observadores.

9 A escrita de Comelles faz isso e mais, porque, quando não revela, sugere, questiona e provoca. Os sonhos de mudança do autor, em plena ditadura franquista, fundamentavam-se em actividades libertadoras (entre as quais se destacam a dedicação ao cinema e à literatura, referências constantes ao longo do texto) e o confronto com a realidade de pedra do manicómio (menos dura no contacto do que as mentalidades da maioria dos directores e dos médicos do hospital), só poderia produzir dor e desilusão. Vão neste sentido as afirmações do autor de que "toda a revolução necessita um projecto que encante, não só uma reivindicação burocratizada" (p. 289) e que "o discurso é um instrumento que permite viver de outro modo a realidade" (p. 290).

A força e a originalidade da obra de Comelles residem no facto de ela cruzar métodos e temas da antropologia e da história, constituir, simultaneamente, um acerto de contas com a realidade e as expectativas de mudança e um exercício de memória compartilhado com o leitor, e, finalmente, revelar uma sólida reflexão sobre o poder, a loucura e, sobretudo, a loucura do poder.

\section{AUTORES}

\section{LUÍS SILVA PEREIRA}

Instituto Superior de Psicologia Aplicada 